\title{
An integrated Decision-Making Approach for Road Transport Evaluation in a Sustainable Supply Chain
}

\author{
Mana. Andarkhora ${ }^{1}$, Amir Hossein. Azadnia ${ }^{2 *}$, Saeid. Emamgholizadeh ${ }^{3}$, Pezhman. \\ Ghadimi $^{4}$
}

\begin{abstract}
One important step to achieve a sustainable transportation system is to control the impact and evaluate the effect of various influencing factors toward three dimensions of sustainability. Within this context, diverse analytical approaches have been developed to assess the sustainability level of various transportation systems, however, sustainability evaluation based on fuzzy multiple criteria decision-making approaches are still limited. In current research activity, an integrated quantitative evaluation technique is proposed to narrow the identified gap. The developed decision-making approach is consisted of two main phases. Firstly, fuzzy analytic hierarchy process is utilized to weigh the sustainability dimensions resulting in the incorporation of the experts' knowledge along with the evaluation process. Then, a proposed fuzzy inference mechanism is proposed to provide an indication on the performance of an evaluated road transportation system. The developed approach is applied on a real-world case study. Finally, future works are presented together with some concluding remarks.
\end{abstract}

Keywords: sustainable supply chain management, sustainable transportation, fuzzy inference system, fuzzy analytic hierarchy process.

Manuscript was received on 21/11/2018, revised on 14/06/2019 and accepted for publication on 19/07/2019.

\section{Introduction}

Brundtland commission defined sustainability as development that meets the needs of the present without compromising the ability of future generations to fulfil their own requirements. Sustainability is bonded with a trade-off between the triple bottom line aspects on achieving economic success, environment cleanness, and social responsibility is introduced by Fairly et al; Olawumi \& Chan and

\footnotetext{
*Corresponding Author.

${ }^{1}$ Department of Management, Shomal University, Amol, Iran, Email: Manaak1370@gmail.com

${ }^{2}$ Department of Industrial Engineering, Ayatollah Amoli Branch, Islamic Azad University, Amol, Iran Email: Azadnia.ie@gmail.com

${ }^{3}$ Department of Management, Shomal University, Amol, Iran, Email: Gholizadehsaeid@gmail.com

${ }^{4}$ Department of Mechanical and Materials Engineering, University College Dublin, Dublin, Irland, Email:Pezhman.ghadimi@ucd.ie
} 
Venkatraman \& nayak [1-3]. According to Takeshita and wang [4, 5], One of the main sources of fossil-fuel consumption and air emission is the increasing usage of commercial fossil-fuel based vehicles. Thus, Bai et al [6] has defined, in order to develop a sustainable supply chain and transportation system, identifying and selecting and sustainability conscious transportation vehicles is of great importance. Transportation has significant economic, social and environmental impacts in a typical supply chain and is one of the most important drivers in achieving sustainability in supply chains. The main aim is to integrate economic, social and environmental requirements of sustainable development at all phases of a transportation system design.

Bongardt et al [7] believed that, In order to devise an effective sustainable planning, a comprehensive evaluation approach is required which simultaneously considers all three dimensions of sustainability. Due to vagueness and ambiguity associated with the sustainability input data, conventional assessment approaches cannot neither suitably nor effectively handle such issues[8]. Decision support tools that can handle such issues would help organizations make more effective supply chain and transportation decisions by research of Fahiminia et al [9, 10]. Also, Vinodh \& davadasan and Rajak et al $[11,12]$ identify that Fuzzy set theory provides a useful approach which eliminates the drawbacks like vagueness, uncertainties, ambiguity, and impreciseness.

An important task for achieving sustainable transport goals is to identify and evaluate the related sustainability criteria. Although, there has been some efforts to identify and evaluate criteria related to sustainable transportation systems by the Awasthi et al, Hsu et al, Reisi et al and Ngossaha et al [13-16], a holistic framework does not exist to act as a roadmap for industrial practitioners and transportation planners as defined Bai et al [6].The main challenge lies within the uncertainty and difficulties in quantifying many related influencing criteria. In addition, few efforts are made for sustainability evaluation of fossil-fuel based transportation vehicles. Therefore, an integrated approach is developed in this research activity to fill the gap in the related literature (see Section 2).

The novelty of the current research activity sits within introducing an integrated multi-criteria decision-making (MCDM) model for sustainable transportation system and its application on a realworld setting. Sustainable transport indicators were determined based logistic experts' opinions and a comprehensive literature review. FAHP was used to weigh the identified criteria and sub criteria selected by the experts. Then, a Fuzzy Inference System (FIS) is proposed to assess the sustainability performance of the considered transportation system. Integrating fuzzy inference mechanism with weighted dimensions results in the inclusive involvement of logistic experts' knowledge which makes the proposed integrated approach more precise than the other existing methods.

The reminder of this paper is as follows. A comprehensive literature review of previously developed tools for road transport evaluation is provided in Section 2. In Section 3, the developed integrated approach is presented in detail. This section is followed by Section 4 in which our case study and results are provided. Finally, some concluding remarks and discussions are provided in Section 5 . 


\section{Literature Review}

\subsection{Road transport evaluation criteria}

In this section, the related sustainable criteria for road transport evaluation are identified and classified into appropriate categories with respect to the triple bottom line defined by Awasthi et al, Bae et al, Bai and Sarkis, Rajak et al, Bai et al, Osorio-Tejada et al [6, 11, 13, 17-19]. The criteria are clustered into various categories due to the multi-faceted nature of sustainable transportation systems. Previous works have elucidated sustainable transportation measures and criteria from different perspectives. For instance, Shiftan et al and Mihyeon Jeon \& Amekudzi [20, 21] analyze that Indicators have been classified into three main categories: environmental indicators: reductions pollution and energy savings; economic indicators: impacts of vehicles characteristics and other system elements (infrastructure, resources or fuels); and social indicators: safety and health, control training, and quality of life by . However, the literature on sustainable transportation management is rather limited. Consequently, a comprehensive list of sustainability indicators is proposed in this article. Table 1 summarizes the results of the proposed criteria categorization for road transport system evaluation.

Table1. Transport sustainability evaluation criteria

\begin{tabular}{|c|c|c|}
\hline $\begin{array}{l}\text { Transportation } \\
\text { Sustainability } \\
\text { Dimensions }\end{array}$ & $\begin{array}{l}\text { Transportation } \\
\text { Sustainability criteria }\end{array}$ & Related Literature \\
\hline \multirow[t]{14}{*}{$\begin{array}{l}\text { Economic } \\
\text { Sustainability } \\
\end{array}$} & Benefit to economy & $\begin{array}{l}\text { Awasthi et al, Griškevičiūtè- } \\
\text { Gečienè, Wang [13, 22, 23] }\end{array}$ \\
\hline & Mobility & $\begin{array}{l}\text { Awasthi et al, Ngossaha et al, } \\
\text { Wang, Mahdini et al[13, 15, } \\
23,24]\end{array}$ \\
\hline & Reliability & Mahdinia et al[24] \\
\hline & $\begin{array}{l}\text { Expenditure and benefit } \\
\text { of transport system } \\
\text { users }\end{array}$ & Mahdinia et al[24] \\
\hline & $\begin{array}{l}\text { Expenditure and } \\
\text { revenues of } \\
\text { transportation system } \\
\text { operators }\end{array}$ & Mahdinia et al[24] \\
\hline & $\begin{array}{l}\text { Investment and } \\
\text { operating cost }\end{array}$ & Wang [23] \\
\hline & Operating revenues & Awasthi \& Omrani[25] \\
\hline & $\begin{array}{l}\text { Transportation total } \\
\text { cost }\end{array}$ & Byrne \& Polonsky[26] \\
\hline & $\begin{array}{l}\text { Transportation system } \\
\text { effectiveness }\end{array}$ & Jeon et al[27] \\
\hline & Economic productivity & Litman[28] \\
\hline & Economic development & Jeon et al, Deakin[27, 29] \\
\hline & Infrastructure costs & Bai et al, Litman[6, 30] \\
\hline & Business opportunities & Ngossaha et al[15] \\
\hline & $\begin{array}{l}\text { Transport system } \\
\text { diversity }\end{array}$ & $\begin{array}{l}\text { Mahdinia et al, Haghshenas } \\
\text { \& Vaziri }[24,31]\end{array}$ \\
\hline
\end{tabular}




\begin{tabular}{|c|c|c|}
\hline & Affordability & Salling \& Pryn[32] \\
\hline & Traffic congestion & $\begin{array}{l}\text { Zhang \& Zhang, Litman, } \\
\text { Litman \& Burwell[5, 30, 33] }\end{array}$ \\
\hline & Traffic safety & $\begin{array}{l}\text { Bai et al, Griškevičiūtè- } \\
\text { Gečiene }[6,22]\end{array}$ \\
\hline & Vehicle price & $\begin{array}{l}\text { Bai et al, Zhao \& Melania[6, } \\
34]\end{array}$ \\
\hline & Vehicle characteristics & Bai et al [6] \\
\hline & Maintenance costs & $\begin{array}{l}\text { Bai et al , Zhao \& Melania [6, } \\
34]\end{array}$ \\
\hline & Running costs & $\begin{array}{l}\text { Bai et al, Reisi et al, Garcia } \\
\& \text { Freire[6, 16, 35] }\end{array}$ \\
\hline & Loading capacity & Bai et al, Litman[6, 36] \\
\hline & Diversity of vehicle & $\begin{array}{l}\text { Mahdinia et al, Haghshenas } \\
\& \text { Vaziri }[24,31]\end{array}$ \\
\hline & $\begin{array}{l}\text { Comfort of use (e.g. } \\
\text { comfortable seats, } \\
\text { accessories) }\end{array}$ & $\begin{array}{l}\text { Bai et al, Awasthi et al, Tzeng } \\
\text { et al }[6,13,37]\end{array}$ \\
\hline & Competency & Awasthi et al[13] \\
\hline & $\begin{array}{l}\text { Improving of } \\
\text { Information technology }\end{array}$ & $\begin{array}{l}\text { Bai et al, Ngossaha et al, } \\
\text { Srisawat et al }[6,15,38]\end{array}$ \\
\hline \multirow{9}{*}{$\begin{array}{l}\text { Social } \\
\text { Sustainability }\end{array}$} & Equity/Fairness & Awasthi et al, Litman[13, 30] \\
\hline & $\begin{array}{l}\text { Fatalities and injuries of } \\
\text { accident }\end{array}$ & Reisi et al, Shiau et al[16, 39] \\
\hline & $\begin{array}{l}\text { Human safety, security } \\
\text { and health }\end{array}$ & $\begin{array}{l}\text { Bai et al, Mahdinia et al, } \\
\text { Djekic et al }[6,24,40]\end{array}$ \\
\hline & Quality of service & Bai et al, Awasthi et al $[6,13]$ \\
\hline & Fuel subsidies & $\begin{array}{l}\text { Bai et al, Byrne \& } \\
\text { Polonsky[6, 26] }\end{array}$ \\
\hline & $\begin{array}{l}\text { Governments subsidies } \\
\text { or incentives }\end{array}$ & $\begin{array}{l}\text { Zhang \& zhang, Bai et al, } \\
\text { Zhao \& Melania, Gracia \& } \\
\text { Freire }[5,6,34,35]\end{array}$ \\
\hline & $\begin{array}{l}\text { The number of } \\
\text { employees }\end{array}$ & Djekic et al[40] \\
\hline & Accessibility & $\begin{array}{l}\text { Awasthi et al, Ngossaha et al, } \\
\text { Reisi et al[13,15,16] }\end{array}$ \\
\hline & Training & $\begin{array}{l}\text { Bai et al, Litman, Russo \& } \\
\text { Comi[6, 41, 42] }\end{array}$ \\
\hline \multirow{5}{*}{$\begin{array}{l}\text { Environmental } \\
\text { Sustainability }\end{array}$} & GHG emissions rate & Bai et al, Awasthi et al $[6,13]$ \\
\hline & $\begin{array}{l}\text { Consumption of natural } \\
\text { resources }\end{array}$ & Zegras[43] \\
\hline & Unit fuel cost & $\begin{array}{l}\text { Bai et al, Byrne \& } \\
\text { Polonsky[6, 26, 35] }\end{array}$ \\
\hline & Alternative fuels & $\begin{array}{l}\text { Bai et al, Byrne \& Polonsky } \\
{[6,26]}\end{array}$ \\
\hline & Energy saving & Bai et al, Awasthi et al $[6,13]$ \\
\hline
\end{tabular}




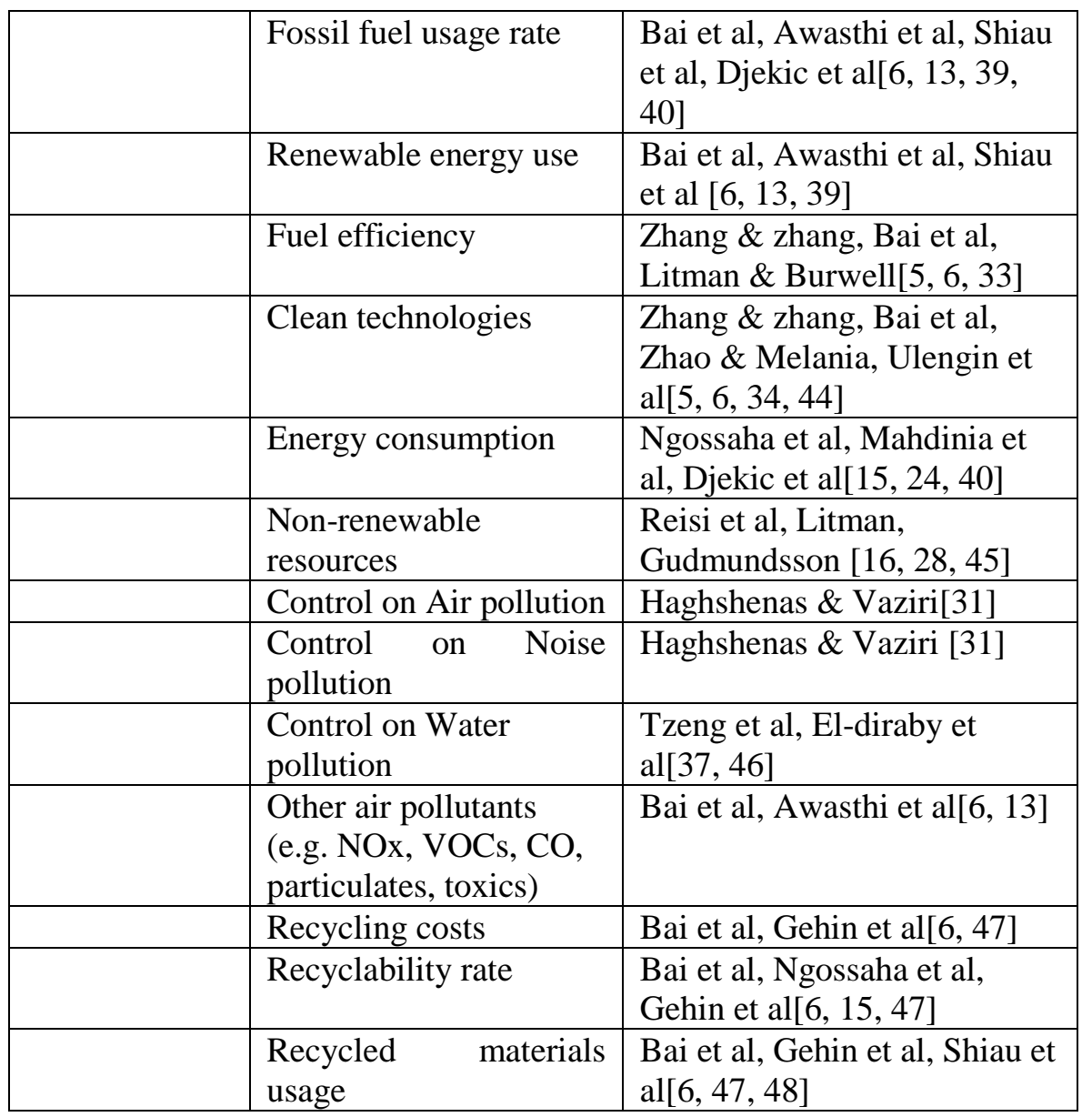

The issue related to sustainable development principles, definition, evaluation and implementation of sustainable transportation system have been studied by several authors. The main challenge in many of these influencing criteria is that they are not often measurable and are associated with uncertainty.

\subsection{Road transport evaluation approaches}

To identify, compare and select sustainable transportation system, efficient decision-making approaches are required. Many approaches have been developed and proposed by academic scholars for sustainability evaluation of transportation systems. Djekic et al [40] provided an analysis of transportation sustainability performance using Life cycle analysis and Fuzzy logic. Garcia \& Freire [35] presented a fleet-based Life cycle approach by analyzing the key aspects underlying environmental and energy impacts of vehicle fleets. Mahdinia et al [24] developed a transportation sustainability index (TSI) to measure the sustainability of transportation systems. They utilized the Principal Component Analysis/Factor Analysis (PCA/FA) methodology and developed an algorithm that produces indices for each of the transportation sustainability dimensions as well as their subdivisions. Shiau et al [39] developed a methodology to evaluate transport sustainability based on rough set theory and two-stage principal component analysis (TSPCA) resulting in aggregating the information from 19 key indicators using available historical 
data. Srisawat [38] proposed a decision support system based on Fuzzy Analytical Hierarchy Process (FAHP) to determine the weights of each sustainability criterion. Furthermore, they integrate the weighted criteria with raster-based analysis and GIS technology to evaluate logistics efficiency. Osorio-Tejada et al [19] presented a systematic approach based on the study of the multidimensional impacts of transportation systems and the application of multi-criteria decision making (MCDM) to assess the sustainability of alternative fuels. Shiau et al [48] applied Fuzzy Cognitive Maps (FCMs) and Analytic Hierarchy Process (AHP) to construct the cause-effect relationships between key indicators and to evaluate sustainable transport strategies. Bai et al [6] proposed a holistic framework for sustainable transport fleet appraisal incorporating various vehicle performance, economic and environmental criteria and introduced a novel hybrid approach for sustainable transportation vehicle evaluation and selection by combining a three-parameter interval grey number with a rough set theory and VIKOR method. Rajak et al [11] presented a fuzzy based approach to evaluate of transport sustainability performance resulting in development of a Fuzzy Transport Sustainability Index (FTSI). Shiau et al [49] integrated data envelopment analysis (DEA) and rough set theory (RST) methods for measuring transport sustainability to achieve effective decision support system for decision-makers. Ngossaha et al [15] presented an integrated approach for assessing the sustainability of the current transportation system design. They aimed at providing decision makers with a framework allowing them to choose the most eco-responsible transportation policy. Awasthi et al [13] proposed a multi-criteria decision-making approach for selecting sustainability transportation systems under partial or incomplete information. Fuzzy TOPSIS was used to generate aggregate scores for sustainability assessment and selection of best alternative. Zhang et al [5] adopted the AHP and Delphi methodologies to establish a comprehensive evaluation index for low carbon road transport systems. Reisi et al [16] developed a method for obtaining a composite transport sustainability index based on statistical local areas (SLAs) and PCA/FA for weighting indicators and avoiding double counting issue among indicators which ultimately provides an unbiased measure of the transport sustainability.

Reviewing the studies in the literature explain some limitations. A few number of indicators had been used to evaluate different aspects of sustainable transportation. Therefore, there is a lack of studies which use a diverse range of indicators to cover the broad and complex goal of sustainability evaluation in transportation systems. Consequently, developing an integrated fuzzy evaluation using all effective criteria have been required.

In this paper, we propose an integrated approach that can be used to evaluate the sustainability performance of vehicles using the identified attributes. Chang's [50]FAHP is utilized to weigh the identified criteria resulting in the incorporation of the experts' knowledge along with the evaluation process. Then, the weighted criteria are incorporated into a proposed fuzzy inference mechanism providing an indication on the performance of an evaluated road transport system. Integrating fuzzy inference mechanism with weighted criteria results in the inclusive involvement of logistic experts' knowledge making the proposed integrated approach more precise than the other existing methods.

\section{Proposed Approach}

The aim of this research is to propose a precise evaluation decision making approach for devising a sustainable road transport system. Firstly, a FAHP model weighting mechanism based on expert's 
ideas within the organization is developed to define importance weights of various identified criteria. Secondly, a fuzzy evaluation mechanism for evaluating the system performance is developed to help decision makers to plan and achieve more sustainable transportation system. In this section, the proposed framework of this research is shown in Figure 1 and explained in detail in the following.

- Step 1: selecting appropriate criteria and sub criteria

- Step 2: weighting the selected criteria

- Step 3: data collection

- Step 4: fuzzy evaluation

- Step 5: determination of sustainability index

A detailed description of each step is described as follows:

In step 1, selecting the criteria and sub criteria is done based on various studies, reviewing the literature and discussion with decision makers. In this study, expert's ideas and logistic experts' knowledge are used for validating the selected criteria and influencing factors. As shown in Figure 1, the environmental, economic and social dimensions related criteria are selected to perform the sustainability assessment.

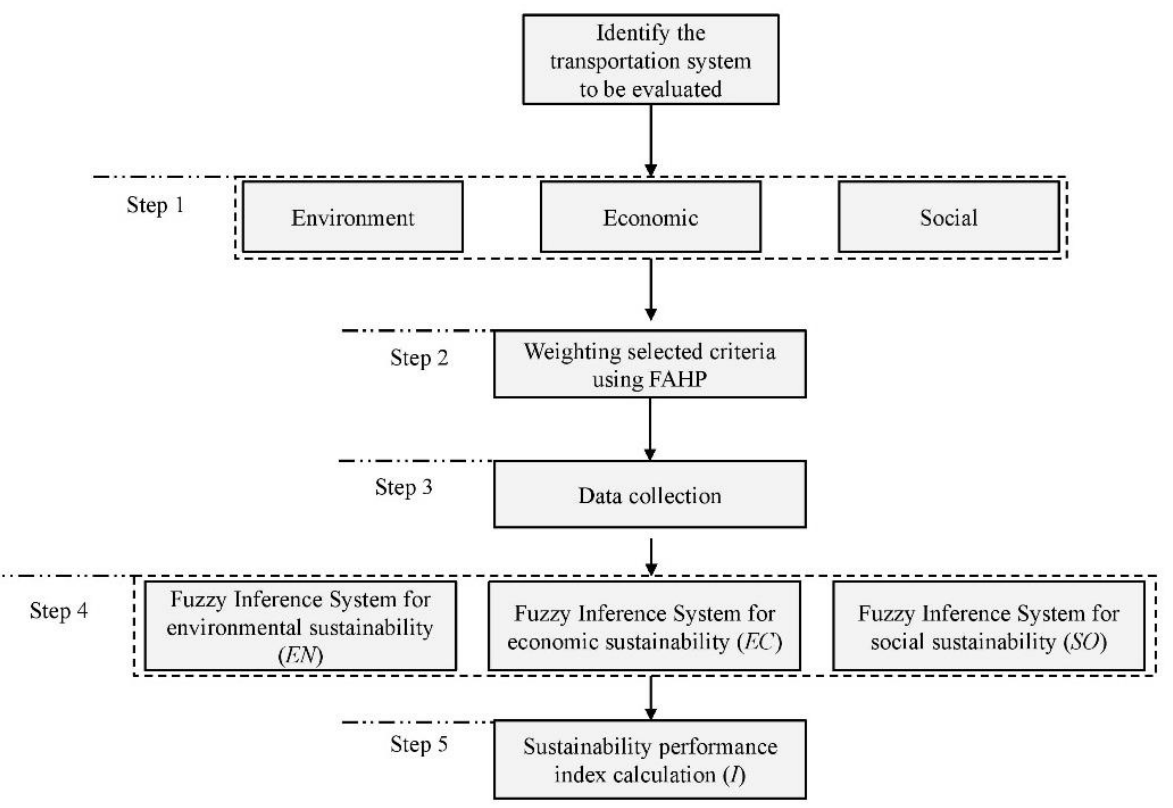

Figure. 1. Research framework used in this study 
In step 2, the criteria and sub criteria of sustainable transportation are weighted using FAHP. Owing to space limitations, the steps of FAHP method are not presented in this paper. Potential readers can refer to Ghadimi et al [51] for a comprehensive description of Chang's (1996) FAHP method. Using these weights will make the assessment more precise and real because calculations of these weights are involved with the decision makers' expert ideas inside the organization.

In step 3, related data are collected from company logistic experts and transport experts. These data are related to the selected environmental economic and social dimension influencing factors.

In step 4, the crisp input and output variables have been transformed into grades of membership for linguistic terms of fuzzy sets. Then, using the fuzzified variables, a fuzzy rule base has been defined. Membership grades of the have been defined based on expert's ideas and also with reviewing the literature. Then, low, medium and high level were selected for input variables. Besides, it was decided to define low, low to medium, medium, medium to high and high as output variable membership grades. Moreover, MATLAB fuzzy logic package is utilized to implement the developed FIS model. The number of fuzzy rules used depends on the number effects and the degree of the input variables, which is determined using Equation 1 Cornelissen et al [52]:

$$
R=n^{v}
$$

where $n$ is number of grades of membership function for input variables and $v$ is the number of input variable for each sustainability criteria and $R$ stands for the number of rules to be constructed.

Step 5 is about the calculation of total current sustainability index. Sustainability index is the aggregate value of the three sustainability dimensions' weighted scores obtained by Equation 3. In this study, overall score for each sub criteria of environmental, economic and social sustainability are calculated by Equation 2 .

$I_{j}=\sum_{i} w_{i j} I_{i j}$

where,

$I_{j}=$ score of $j^{\text {th }}$ sustainability dimension,

$W_{i j}=$ weight of $i^{\text {th }}$ influencing factor of $j^{\text {th }}$ sustainability dimension,

$I_{i j}=$ score of $i^{\text {th }}$ influencing factor of $j^{\text {th }}$ sustainability dimension,

$i=1$.....nindex of influencing factor,

$j=$ Environmental $(E N)$, Economic $(E C)$ and Social $(S O)$ 
$I_{\text {sustainability }}=w_{E N} I_{E N}+w_{E C} I_{E C}+w_{S O} I_{S O}$

where,

$I_{E N}=$ score of environmental sustainability,

$I_{E C}=$ score of economic sustainability,

$I_{S O}=$ score of social sustainability,

$w_{E N}=$ weight of environmental sustainability,

$w_{E C}=$ weight of economic sustainability,

$w_{S O}=$ weight of social sustainability,

$I_{\text {sustainability }}=$ total sustainability index.

\section{Case study and Result}

A critical component of sustainable transport planning is the development of an integrated evaluation program that evaluates transport system performance based on an appropriate set of environmental, social and economic indicators by the researches of Bongardt et al [7]. Hence, to broaden the perspective of sustainability in all three dimensions (environmental, social and economic), methodologies have been proposed to evaluate the sustainability aspects of a given transport system. Such decision support tools and methodologies can help organizations to be more effective in sustainability decisions. As the Singh \& Bailey and Zadeh \& Aredebilipour [53, 54] evaluated, In order to evaluate sustainability aspect, fuzzy set theory can provide an appropriate foundation because it enables modeling of complex systems using ill-defined dynamics and inputs such as the situation considered in this study.

The goal of the proposed integrated technique is different from other approaches in term of the filtration and ranking processes. The developed methodology seeks to evaluate the most effective factors of sustainable transportation systems accurately and identify the destructive factors in companies. In order to evaluate, compare and select sustainable transportation system, efficient decision-making approaches are required. In this section, details about the case companies, data collection, sustainability assessment and comparison of transportation systems are presented.

\section{- Step 1: About the case companies}

This case study was conducted in three Iranian companies. Parastoo, Jam and Arya companies were selected, and their transportation systems have been evaluated and compared with regards to the sustainability aspects. The aim of this study is the sustainability evaluation of these companies using the proposed evaluation approach in previous section. 


\section{- Step 2: Criteria selection}

In this study, selecting the influencing factors is done based on reviewing the literature, Reisi et al, Shiau et al, Rajak et al, Bai et al, Ngossaha et al, Osorio-Tejada et al, Fathi \& Saen, Mahdinia et al $[6,11,15,16,19,24,39,55]$ and discussion with the decision makers and accessing the companies' historical records. The group of decision makers in this study are consisted of logistic experts and general managers inside each company. These experts' opinions are used for validating the selected influencing factors. The identified influencing factors are classified into the three sustainability dimensions, i.e., environmental, economic and social. Table 2 tabulates the selected influencing factors with respect to each sustainability dimension.

Table 2. Selected influencing factors for evaluating the sustainable transportation system

\begin{tabular}{ll}
\hline Dimension & Influencing factor \\
\hline Economic & Benefit to economy \\
Reliability \\
Expenditure of transportation system operators \\
Operating revenues \\
Transportation total cost \\
Economic productivity \\
Infrastructure costs \\
Maintenance costs \\
Running costs \\
Loading capacity \\
Diversity of vehicle \\
Comfort of use (e.g. comfortable seats, accessories) \\
Improving of Information technology \\
GHG emissions rate \\
Consumption of natural resources \\
Alternative fuels \\
Energy saving \\
Renewable energy use \\
Clean technologies \\
Control on Air pollution \\
Control on Noise pollution \\
Control on Water pollution \\
Recyclability rate \\
Equity/Fairness \\
Fatalities and injuries of accident \\
Human safety, security and health \\
Quality of service \\
Training \\
The number of employees \\
\hline
\end{tabular}

- Step 3: Weighting selected influencing factors using FAHP

In this step, the three sustainability dimensions of sustainable transportation have been weighted using FAHP. The hierarchy structure including three levels has been made according to Table 2. 
Levels present the main goal which is the sustainability index, dimensions and influencing factors. The linguistic variables and their corresponding fuzzy numbers are shown in Table 3. Based on fuzzy scales, company's experts as a group were asked to perform pairwise comparison to achieve the weights of three sustainability dimensions. The experts compared the sustainability dimensions with respect to the total sustainability index. The results of these pairwise comparisons are shown in Table 4. Consequently, based on Chang's FAHP steps, the three sustainability dimensions have been weighted. Owing to the limitation on space, only the final weights of these dimensions are presented in Table 5.

Table 3. The linguistic variables and their corresponding fuzzy numbers

\begin{tabular}{ll}
\hline Linguistic scale & Triangular fuzzy scale \\
\hline Just equal & $(1,1,1)$ \\
\hline Weakly important & $(2 / 3,1,3 / 2)$ \\
\hline Strongly important & $(1,3 / 2,2)$ \\
\hline Very strong important & $(3 / 2,2,5 / 2)$ \\
\hline Absolutely more important & $(2,5 / 2,3)$ \\
\hline
\end{tabular}

Table 4. Fuzzy pairwise comparisons

\begin{tabular}{llll}
\hline & Environment & Economic & Social \\
\hline Environment & $(1,1,1)$ & $(2 / 3,1,3 / 2)$ & $(1,3 / 2,2)$ \\
\hline Economic & $(2 / 3,1,3 / 2)$ & $(1,1,1)$ & $(2 / 3,1,3 / 2)$ \\
\hline Social & $(1 / 2,2 / 3,1)$ & $(2 / 3,1,3 / 2)$ & $(1,1,1)$ \\
\hline
\end{tabular}

Table 5. Results of the dimension weights

\begin{tabular}{ll}
\hline Dimensions & Weight \\
\hline Environment & 0.3837 \\
\hline Economic & 0.3301 \\
\hline Social & 0.286
\end{tabular}

- Step 4: Data collection

For environmental dimension, 10 influencing factors were selected. For economic category, 13 influencing factors and for social dimensions, six factors were selected. The influencing factors data were collected based on discussions and meetings help with each company's decision makers (logistic/transport experts and general managers). The collected data with respect to each of these influencing factors are shown in Table 6.

Table 6. Amount of parameters

\begin{tabular}{llll}
\hline Influencing factors & Parastoo & Jam & Arya \\
\hline Benefit to economy & Very high & High & High \\
Reliability & Very high & High & Very high \\
$\begin{array}{l}\text { Expenditure of } \\
\text { transportation system } \\
\text { operators }\end{array}$ & 36000000 & 304000000 & 68000000 \\
Operating revenues & 118000000 & 320000000 & 280000000 \\
\hline
\end{tabular}




\begin{tabular}{|c|c|c|c|}
\hline $\begin{array}{l}\text { Transportation total } \\
\text { cost }\end{array}$ & 72000000 & 450000000 & 400000000 \\
\hline Economic productivity & Very high & High & High \\
\hline Infrastructure costs & 18000000 & 62000000 & 48000000 \\
\hline Maintenance costs & 12000000 & 60000000 & 216000000 \\
\hline Running costs & 6000000 & 24000000 & 68000000 \\
\hline Loading capacity & 0.85 & 0.6 & 0.3 \\
\hline Diversity of vehicle & 6 & 2 & 3 \\
\hline $\begin{array}{l}\text { Comfort of use (e.g. } \\
\text { comfortable seats, } \\
\text { accessories) }\end{array}$ & High & High & Medium \\
\hline $\begin{array}{l}\text { Improving of } \\
\text { Information technology }\end{array}$ & High & High & Medium \\
\hline GHG emissions rate & 0.8 & 0.55 & 0.3 \\
\hline $\begin{array}{l}\text { Consumption of natural } \\
\text { resources }\end{array}$ & High & Medium & Medium \\
\hline Alternative fuels & High & Medium & Medium \\
\hline Energy saving & High & High & Medium \\
\hline Renewable energy use & Very high & High & High \\
\hline Clean technologies & Very high & Medium & Medium \\
\hline $\begin{array}{l}\text { Control on Air } \\
\text { pollution }\end{array}$ & Medium & High & High \\
\hline $\begin{array}{l}\text { Control on Water } \\
\text { pollution }\end{array}$ & High & High & High \\
\hline $\begin{array}{l}\text { Control on Noise } \\
\text { pollution }\end{array}$ & Very high & High & Medium \\
\hline Recyclability rate & 0.3 & 0.25 & 0.2 \\
\hline Equity/Fairness & High & High & High \\
\hline $\begin{array}{l}\text { Fatalities and injuries of } \\
\text { accident }\end{array}$ & 0 & 0 & 0 \\
\hline $\begin{array}{l}\text { Human safety, security } \\
\text { and health }\end{array}$ & Medium & High & High \\
\hline Quality of service & Medium & High & High \\
\hline Training & Very low & High & High \\
\hline $\begin{array}{l}\text { The number of } \\
\text { employees }\end{array}$ & 50 & 25 & 15 \\
\hline
\end{tabular}

\section{- Step 5: Fuzzy evaluation}

At first, in this section, the crisp input and output variables have been transformed into grades of membership for linguistic terms of fuzzy sets, as shown in Tables 7-9. Then, a fuzzy rule base has been constituted using the fuzzified variables. Membership grades of the crisp input and output variables have been defined based on decision maker's opinion. Then, low, medium and high were selected for input variables. Besides, it was decided to define low, low to medium, medium, medium to high and high as output variable membership grades. Moreover, MATLAB fuzzy logic package was utilized in step 5 .

Table 7. The membership functions of environmental sub criteria 


\begin{tabular}{|c|c|c|c|}
\hline $\begin{array}{l}\text { Linguistics } \\
\text { value }\end{array}$ & Numerical range & $\begin{array}{l}\text { Linguistics } \\
\text { value }\end{array}$ & $\begin{array}{l}\text { Numerical } \\
\text { range }\end{array}$ \\
\hline $\begin{array}{l}\text { GHG } \\
\text { emission } \\
\text { rate: }\end{array}$ & & $\begin{array}{l}\text { Clean } \\
\text { technology }\end{array}$ & \\
\hline Low & {$\left[\begin{array}{llll}0 & 0.25 & 0.5\end{array}\right]$} & Low & {$\left[\begin{array}{lll}0 & 1 & 2\end{array}\right]$} \\
\hline Medium & {$\left[\begin{array}{llll}0.25 & 0.5 & 0.75\end{array}\right]$} & Medium & {$\left[\begin{array}{lll}1 & 2 & 3\end{array}\right]$} \\
\hline High & {$\left[\begin{array}{lll}0.5 & 0.75 & 1\end{array}\right]$} & High & {$\left[\begin{array}{lll}2 & 3 & 4\end{array}\right]$} \\
\hline $\begin{array}{l}\text { Consumption } \\
\text { of natural } \\
\text { resource: }\end{array}$ & & Control on air & \\
\hline Low & {$\left[\begin{array}{lll}0 & 1 & 2\end{array}\right]$} & Low & {$\left[\begin{array}{lll}0 & 1 & 2\end{array}\right]$} \\
\hline Medium & {$\left[\begin{array}{lll}1 & 2 & 3\end{array}\right]$} & Medium & {$\left[\begin{array}{lll}1 & 2 & 3\end{array}\right]$} \\
\hline High & {$\left[\begin{array}{lll}2 & 3 & 4\end{array}\right]$} & High & {$\left[\begin{array}{lll}2 & 3 & 4\end{array}\right]$} \\
\hline $\begin{array}{l}\text { Alternative } \\
\text { fuels }\end{array}$ & & $\begin{array}{ll}\text { Control on } \\
\text { water }\end{array}$ & \\
\hline Low & {$\left[\begin{array}{lll}0 & 1 & 2\end{array}\right]$} & Low & {$\left[\begin{array}{lll}0 & 1 & 2\end{array}\right]$} \\
\hline Medium & {$\left[\begin{array}{lll}1 & 2 & 3\end{array}\right]$} & Medium & {$\left[\begin{array}{lll}1 & 2 & 3\end{array}\right]$} \\
\hline High & {$\left[\begin{array}{lll}2 & 3 & 4\end{array}\right]$} & High & {$\left[\begin{array}{lll}2 & 3 & 4\end{array}\right]$} \\
\hline $\begin{array}{l}\text { Energy } \\
\text { saving }\end{array}$ & & $\begin{array}{l}\text { Control } \\
\text { noise }\end{array}$ & \\
\hline Low & {$\left[\begin{array}{lll}0 & 1 & 2\end{array}\right]$} & Low & {$\left[\begin{array}{lll}0 & 1 & 2\end{array}\right]$} \\
\hline Medium & {$\left[\begin{array}{lll}1 & 2 & 3\end{array}\right]$} & Medium & {$\left[\begin{array}{lll}1 & 2 & 3\end{array}\right]$} \\
\hline High & {$\left[\begin{array}{lll}2 & 3 & 4\end{array}\right]$} & High & {$\left[\begin{array}{llll}2 & 3 & 4\end{array}\right]$} \\
\hline $\begin{array}{l}\text { Renewable } \\
\text { energy use }\end{array}$ & & Recyclable rate & \\
\hline Low & {$\left[\begin{array}{lll}0 & 1 & 2\end{array}\right]$} & Low & {$\left[\begin{array}{lll}0 & 1 & 2\end{array}\right]$} \\
\hline Medium & {$\left[\begin{array}{lll}1 & 2 & 3\end{array}\right]$} & Medium & {$\left[\begin{array}{lll}1 & 2 & 3\end{array}\right]$} \\
\hline High & {$\left[\begin{array}{lll}2 & 3 & 4\end{array}\right]$} & High & {$\left[\begin{array}{lll}2 & 3 & 4\end{array}\right]$} \\
\hline
\end{tabular}

Table 8. The membership functions of economic sub criteria

\begin{tabular}{|c|c|c|c|}
\hline $\begin{array}{l}\text { Linguistics } \\
\text { value }\end{array}$ & Numerical range & $\begin{array}{l}\text { Linguistics } \\
\text { value }\end{array}$ & Numerical range \\
\hline $\begin{array}{ll}\text { Benefit } & \text { to } \\
\text { economy: } & \end{array}$ & & $\begin{array}{l}\text { Economic } \\
\text { productivity: }\end{array}$ & \\
\hline Low & {$\left[\begin{array}{llll}0 & 0.25 & 0.5\end{array}\right]$} & Low & {$\left[\begin{array}{lll}0 & 1 & 2\end{array}\right]$} \\
\hline Medium & {$\left[\begin{array}{llll}0.25 & 0.5 & 0.75\end{array}\right]$} & Medium & {$\left[\begin{array}{lll}1 & 2 & 3\end{array}\right]$} \\
\hline High & {$\left[\begin{array}{llll}0.5 & 0.75 & 1\end{array}\right]$} & High & {$\left[\begin{array}{lll}2 & 3 & 4\end{array}\right]$} \\
\hline Reliability: & & $\begin{array}{l}\text { Loading } \\
\text { capacity: }\end{array}$ & \\
\hline Low & $\left.\begin{array}{lll}0 & 1 & 2\end{array}\right]$ & Low & {$\left[\begin{array}{llll}0 & 0.25 & 0.5\end{array}\right]$} \\
\hline Medium & {$\left[\begin{array}{lll}1 & 2 & 3\end{array}\right]$} & Medium & {$\left[\begin{array}{llll}0.25 & 0.5 & 0.75\end{array}\right]$} \\
\hline High & {$\left[\begin{array}{lll}2 & 3 & 4\end{array}\right]$} & High & {$\left[\begin{array}{llll}0.5 & 0.75 & 1\end{array}\right]$} \\
\hline $\begin{array}{l}\text { Expenditure } \\
\text { of transport } \\
\text { system } \\
\text { operators: }\end{array}$ & & $\begin{array}{l}\text { Diversity } \\
\text { vehicles: }\end{array}$ & \\
\hline
\end{tabular}




\begin{tabular}{|c|c|c|c|}
\hline Low & $\begin{array}{l}{[083600000} \\
167200000] \\
\end{array}$ & Low & {$\left[\begin{array}{llll}0 & 1.75 & 3.5\end{array}\right]$} \\
\hline Medium & $\begin{array}{l}{[83600000} \\
167200000 \\
250800000]\end{array}$ & Medium & {$\left[\begin{array}{llll}1.75 & 3.5 & 5.25\end{array}\right]$} \\
\hline High & $\begin{array}{l}{[167200000} \\
250800000 \\
334400000]\end{array}$ & High & {$\left[\begin{array}{llll}3.5 & 5.25 & 7\end{array}\right]$} \\
\hline $\begin{array}{l}\text { Operating } \\
\text { revenues: }\end{array}$ & & $\begin{array}{l}\text { Comfort } \\
\text { use: }\end{array}$ & \\
\hline Low & $\begin{array}{l}{[088000000} \\
176000000]\end{array}$ & Low & {$\left[\begin{array}{lll}0 & 1 & 2\end{array}\right]$} \\
\hline Medium & $\begin{array}{l}{[88000000} \\
176000000 \\
264000000] \\
\end{array}$ & Medium & {$\left[\begin{array}{lll}1 & 2 & 3\end{array}\right]$} \\
\hline High & $\begin{array}{l}{[176000000} \\
264000000 \\
352000000]\end{array}$ & High & {$\left[\begin{array}{lll}2 & 3 & 4\end{array}\right]$} \\
\hline $\begin{array}{l}\text { Transport } \\
\text { total cost: }\end{array}$ & & $\begin{array}{l}\text { Infrastruc } \\
\text { costs: }\end{array}$ & \\
\hline Low & $\begin{array}{l}{\left[\begin{array}{ll}0 & 123750000 \\
247500000\end{array}\right]} \\
\end{array}$ & Low & $\begin{array}{l}{\left[\begin{array}{ll}0 & 17050000 \\
34100000]\end{array}\right.} \\
\end{array}$ \\
\hline Medium & $\begin{array}{l}{[123750000} \\
247500000 \\
371250000]\end{array}$ & Medium & $\begin{array}{l}{[17050000} \\
34100000 \\
51150000] \\
\end{array}$ \\
\hline High & $\begin{array}{l}{[247500000} \\
371250000 \\
495000000]\end{array}$ & High & $\begin{array}{l}{[34100000} \\
51150000 \\
68200000] \\
\end{array}$ \\
\hline $\begin{array}{l}\text { Maintenance } \\
\text { costs: }\end{array}$ & & Running & \\
\hline Low & $\begin{array}{l}059400000 \\
118800000]\end{array}$ & Low & $\begin{array}{l}\begin{array}{ll}0 & 18700000 \\
37400000]\end{array} \\
\end{array}$ \\
\hline Medium & $\begin{array}{l}{[59400000} \\
118800000 \\
178200000]\end{array}$ & Medium & $\begin{array}{l}{[18700000} \\
37400000 \\
56100000]\end{array}$ \\
\hline High & $\begin{array}{l}{[118800000} \\
178200000 \\
237600000]\end{array}$ & High & $\begin{array}{l}{[37400000} \\
56100000 \\
74800000 \\
\end{array}$ \\
\hline \multicolumn{4}{|l|}{$\begin{array}{l}\text { Improving of } \\
\text { IT: }\end{array}$} \\
\hline Low & {$\left[\begin{array}{lll}0 & 1 & 2\end{array}\right]$} & & \\
\hline Medium & {$\left[\begin{array}{lll}1 & 2 & 3\end{array}\right]$} & & \\
\hline High & {$\left[\begin{array}{lll}2 & 3 & 4\end{array}\right]$} & & \\
\hline
\end{tabular}

Table 9. The membership functions of social sub criteria

\begin{tabular}{llll}
\hline $\begin{array}{l}\text { Linguistics } \\
\text { value }\end{array}$ & Numerical range & $\begin{array}{l}\text { Linguistics } \\
\text { value }\end{array}$ & $\begin{array}{l}\text { Numerical } \\
\text { range }\end{array}$ \\
\hline Equity/fairness: & Quality & of \\
\hline
\end{tabular}




\begin{tabular}{llll}
\hline \multicolumn{4}{l}{ services: } \\
\hline Low & {$\left[\begin{array}{lll}0 & 1 & 2\end{array}\right]$} & Low & {$\left[\begin{array}{lll}0 & 1 & 2\end{array}\right]$} \\
\hline Medium & {$\left[\begin{array}{lll}1 & 2 & 3\end{array}\right]$} & Medium & {$\left[\begin{array}{lll}1 & 2 & 3\end{array}\right]$} \\
\hline High & {$\left[\begin{array}{lll}2 & 3 & 4\end{array}\right]$} & High & {$\left[\begin{array}{lll}2 & 3 & 4\end{array}\right]$} \\
\hline $\begin{array}{l}\text { Fatalities } \\
\text { injuries } \\
\text { accident: }\end{array}$ & $\begin{array}{r}\text { and } \\
\text { of }\end{array}$ & $\begin{array}{l}\text { The number of } \\
\text { employees: }\end{array}$ \\
\hline Low & {$\left[\begin{array}{llll}0 & 2.5 & 5\end{array}\right]$} & Low & {$\left[\begin{array}{lll}0 & 15 & 30\end{array}\right]$} \\
\hline Medium & {$\left[\begin{array}{llll}2.5 & 5 & 7.5\end{array}\right]$} & Medium & {$\left[\begin{array}{lll}15 & 30 & 45\end{array}\right]$} \\
\hline High & {$\left[\begin{array}{llll}5 & 7.5 & 10\end{array}\right]$} & High & {$\left[\begin{array}{llll}30 & 45 & 60\end{array}\right]$} \\
\hline $\begin{array}{l}\text { Human safety } \\
\text { and health: }\end{array}$ & & Training: & \\
\hline Low & {$\left[\begin{array}{lll}0 & 1 & 2\end{array}\right]$} & Low & {$\left[\begin{array}{lll}0 & 1.5 & 3\end{array}\right]$} \\
\hline Medium & {$\left[\begin{array}{llll}1 & 2 & 3\end{array}\right]$} & Medium & {$\left[\begin{array}{llll}1.5 & 3 & 4.5\end{array}\right]$} \\
\hline High & {$\left[\begin{array}{llll}2 & 3 & 4\end{array}\right]$} & High & {$\left[\begin{array}{llll}3 & 4.5 & 6\end{array}\right]$} \\
\hline
\end{tabular}

Equation 1 was used to compute the number of rules to be constructed for each sustainability dimensions. Some realistic rules of the rule base have been created by decision maker's knowledge. A sample of these fuzzy IF-THEN rules is given in Table 10. These rules determine the sustainability index from some input variables and membership grades (low, medium and high).

Table 10. Some rule examples from the rule base

\begin{tabular}{|l|l|}
\hline Rule no. & Rules \\
\hline Rule 1 & $\begin{array}{l}\text { IF (benefit to economy is low) AND (reliability is low) } \\
\text { AND (expenditure of operators is low) THEN (output is } \\
\text { low) }\end{array}$ \\
\hline Rule 2 & $\begin{array}{l}\text { IF (alternative fuels is medium) AND (energy saving is } \\
\text { high) THEN (output is high) }\end{array}$ \\
\hline Rule 3 & $\begin{array}{l}\text { If (loading capacity is high) AND (improving of IT is } \\
\text { medium) AND (infrastructure costs is medium) THEN } \\
\text { (output is high) }\end{array}$ \\
\hline Rule 4 & $\begin{array}{l}\text { If (services quality is medium) AND (training is high) } \\
\text { THEN (output is high) }\end{array}$ \\
\hline Rule 5 & $\begin{array}{l}\text { If (GHG rate is low) AND (consumption of resource is } \\
\text { high) THEN (output is medium) }\end{array}$ \\
\hline Rule 6 & $\begin{array}{l}\text { If (equity is low) AND (safety is medium) THEN (output } \\
\text { is low) }\end{array}$ \\
\hline Rule 7 & $\begin{array}{l}\text { If (control of noise is medium) AND (recyclability rate is } \\
\text { high) THEN (output is high) }\end{array}$ \\
\hline
\end{tabular}

\section{- Step 6: Determination of the sustainability elements index}

Overall scores for the environmental, economic and social sustainability dimensions were calculated using Equation 2. Table 11 demonstrates the obtained scores for each sustainability dimension. Based on these results, the total sustainability index was calculated using Equation 3 (see Table 12). The three companies involved in this study were ranked based on their sustainability 
index. According to Table 12, Jam company had the best performance index for their employed road transportation system.

Table 11. Overall sustainability score of each case company

\begin{tabular}{lllllll}
\hline \multirow{2}{*}{ Company } & \multicolumn{2}{l}{ Environmental aspect } & Economic aspect & \multicolumn{2}{l}{ Social aspect } \\
\cline { 2 - 7 } & $\begin{array}{l}\text { unweighte } \\
\text { d score }\end{array}$ & $\begin{array}{l}\text { weighted } \\
\text { score }\end{array}$ & $\begin{array}{l}\text { unweight } \\
\text { ed score }\end{array}$ & $\begin{array}{l}\text { weighte } \\
\text { d score }\end{array}$ & $\begin{array}{l}\text { unweighte } \\
\text { d score }\end{array}$ & $\begin{array}{l}\text { weighted } \\
\text { score }\end{array}$ \\
\hline Parastoo & 0.55 & 0.211 & 0.681 & 0.2248 & 0.583 & 0.1667 \\
\hline Jam & 0.8 & 0.3069 & 0.652 & 0.2152 & 0.723 & 0.2067 \\
\hline Arya & 0.7 & 0.2685 & 0.394 & 0.1294 & 0.783 & 0.2239 \\
\hline
\end{tabular}

Table 12. Final score of sustainability index for companies

\begin{tabular}{lll}
\hline Company & Sustainability score & Rank \\
\hline Parastoo & 0.6025 & 3 \\
\hline Jam & 0.7288 & 1 \\
\hline Arya & 0.6218 & 2 \\
\hline
\end{tabular}

As shown in Figure 2, although the overall sustainability index of Jam company is scored as the highest among the three companies, it is found that it is ranked as the best performing company only regarding environmental aspect $(0.8>0.7>0.55)$. Besides, Parastoo company's economic sustainability is the best among the three companies $(0.681>0.652>0.394)$, however, its overall sustainability index was ranked as the worst one. This important finding strengthens the fact that companies that try to devise cost-efficient systems would usually lag behind the social and environmental sustainability aspect of sustainable development. This important finding was also highlighted by Ghadimi et al, Zimmer et al [56-59]. 


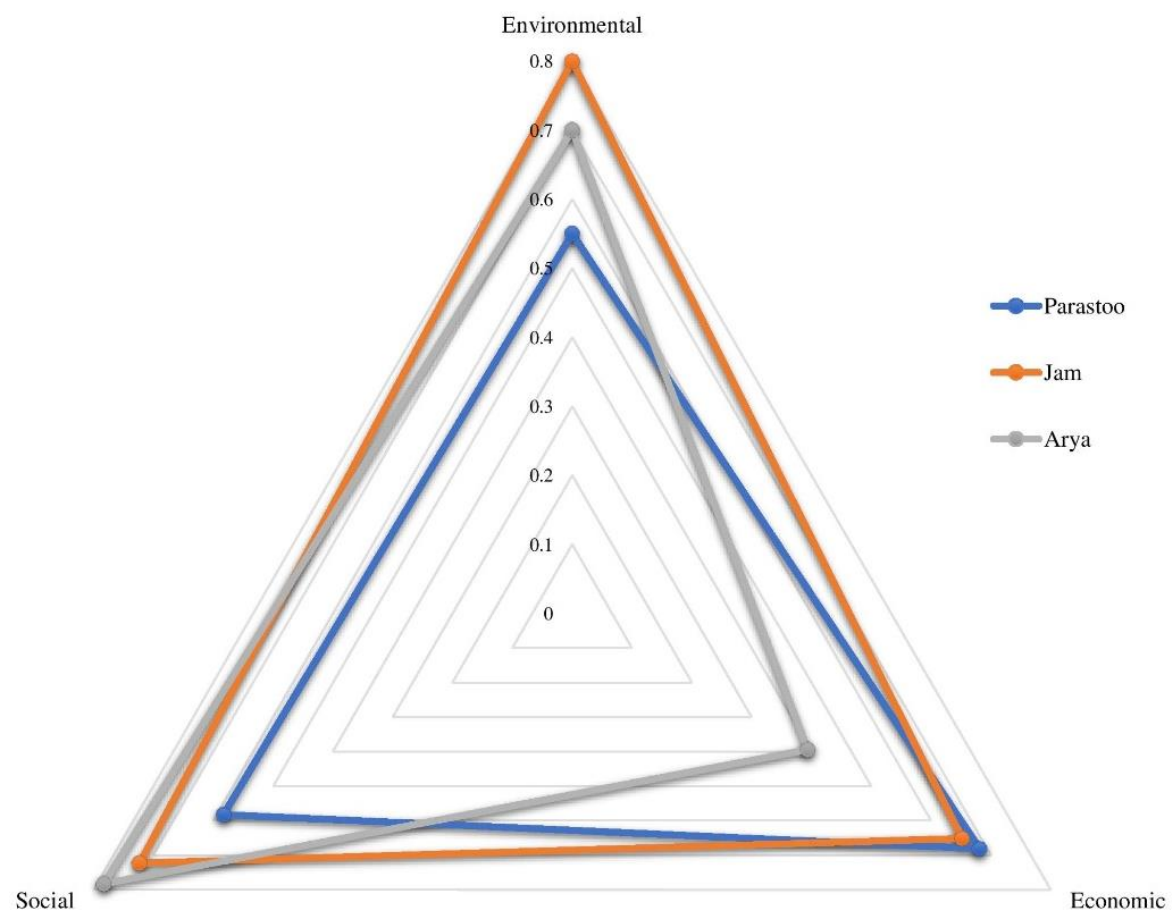

Figure 2. Sustainability dimension scores comparisons

By further investigating the results depicted in Figure 2, it can be observed that Arya company's sustainability performance in terms of environmental and social sustainability is almost the best comparing with the other two companies. However, these good performances resulted in a low economic sustainability score. Therefore, not always performing well in one or two dimensions of sustainable development can guarantee a good overall performance. As also highlighted by Ghadimi et al [57] companies need to always seek for trade-offs between all dimensions of sustainability. Providing a sustainable service or product to end-customers requires companies to improve their systems (in general) with regards to all aspects of sustainable development in a simultaneous manner.

\section{Conclusion}

Commercial vehicles usage is one of the most important sources of fossil-fuel consumption and air pollutants emission that affects our environment, society and economy. Moreover, Fahiminia et al [60] realized that an unsustainable transportation system can lead to excessive waste and use of toxic material. Given the critical significance of the environmental burdens of transportation activities the development of decision support tools for evaluation of sustainable transportation system deem to be required. In this research article, an FIS based evaluation mechanism was developed to compare and rank the considered transportation systems within the three case companies. As managerial implications, it was found that the FIS approach provides the managers and decision makers with a deeper understanding and insights about the actual sustainability issues within their organizations. As theoretical implications, the current research work narrows the gap identifies in the literature in terms of a lack in utilizing fuzzy inference approach in measuring the sustainability practices of road transportation systems. 
This research contributes to this area by introducing an integrated MCDM technique which has been proposed to solve the problem of sustainable transportation performance evaluation. Firstly, FAHP method was utilized to calculate the weights of sustainability dimensions. Next, a FIS model has been developed to evaluate various sustainable transportation system. The resulting indicator is a sustainability performance index acting as a mean to compare various evaluated transportation systems. This approach allows for consideration of intangibility and ambiguity from expert judgment amongst the sustainability dimensions. The main strength of this approach is its ability to treat heterogeneous, uncertain and incomplete data coming from multiple information sources. Providing the influencing factors with regards to each sustainability dimension for assessing a given transportation system in a tabular framework can be considered as another contribution of this work. The methodology was implemented using real world data collected from industry experts in three related industrial organizations.

For future work, there are opportunities to develop a comprehensive framework and mathematical programming models for sustainable transportation system which consider all dimensions of sustainable development aiming to provide a trade-off between economic aspects with environmental and social issues.

\section{References}

[1] Fairley S, Tyler, B.D., Kellett, P., D’Elia, K. (2011), The Formula one Australian Grand Prix: exploring the triple bottom line. Sport Management Review, 14(2):141152.

[2] Olawumi TO, \& Chan, D. W. (2018). A scientometric review of global research on sustainability and sustainable development. Journal of Cleaner Production.

[3] Venkatraman S, \& Nayak, R. R. (2015). Corporate sustainability: an IS approach for integrating triple bottom line elements. Social Responsibility Journal, 11(3):482501.

[4] Takeshita T. (2012). Assessing the co-benefits of CO2 mitigation on ai pollutants emissions from road vehicles. Applied Energy (97):225-237.

[5] Zhang W, Lu, J., \& Zhang, Y. (2016). Comprehensive evaluation index system of low carbon road transport based on fuzzy evaluation method. Procedia engineering (137):659-668.

[6] Bai C, Fahimnia, B., \& Sarkis, J. (2017). Sustainable transport fleet appraisal using a hybrid multi-objective decision making approach. Annals of Operations Research, 250(2):309-340.

[7] Bongardt D, Schmid, D., Huizenga, C., \& Litman, T. (2011). Sustainable transport evaluation: Developing practical tools for evaluation in the context of the CSD process. . Partnership on Sustainable Low Carbon Transport, Eschborn, Germany.

[8] Lin YH, Lee, P. C., \& Ting, H. I.(2008). Dynamic multi-attribute decision making model with grey number evaluations. Expert Systems with Applications, 
35(4):1638-1644.

[9] Fahimnia B, Sarkis, J., \& Eshragh, A. (2015e). A tradeoff model for green supply chain planning: A leannessversus-greenness analysis. Omega (54):173-190.

[10] Fahimnia B, Sarkis, J., Dehghanian, F., Banihashemi, N., \& Rahman, S. (2013b). The impact of carbon pricing on a closed-loop supply chain: An Australian case study. Journal of Cleaner Production (59):210-225.

[11] Rajak S, Parthiban, P., \& Dhanalakshmi, R. (2016). Sustainable transportation systems performance evaluation using fuzzy logic. Ecological Indicators (71):503513.

[12] Vinodh S, \& Devadasan, S. R. (2011). Twenty criteria based agility assessment using fuzzy logic approach. The International Journal of Advanced Manufacturing Technology, 54(9):1219-1231.

[13] Awasthi A, Chauhan, S. S., \& Omrani, H. (2011). Application of fuzzy TOPSIS in evaluating sustainable transportation systems. Expert Systems with Applications, 38(10):12270-12280.

[14] Hsu CY, Yang, C. S., Yu, L. C., Lin, C. F., Yao, H. H., Chen, D. Y., et al.(2014). Development of a cloud-based service framework for energy conservation in a sustainable intelligent transportation system. International Journal of Production Economics (164):454-461.

[15] Ngossaha JM, Ngouna, R. H., Archimède, B., \& Nlong, J. M. (2017). Sustainability assessment of a transportation system under uncertainty: an integrated multicriteria approach. IFAC-PapersOnLine, 50(1):7481-7486.

[16] Reisi M, Aye, L., Rajabifard, A., \& Ngo, T. (2014). Transport sustainability index: Melbourne case study. Ecological Indicators (43):288-296.

[17] Bae SH, Sarkis, J., \& Yoo, C. S. (2011). Greening transportation fleets: Insights from a two-stage game theoretic model. Transportation Research Part E: Logistics and Transportation Review, 47(6):793-807.

[18] Bai C, \& Sarkis, J. (2013b). Flexibility in reverse logistics: A framework and evaluation approach. Journal of Cleaner Production (47):306-318.

[19] Osorio-Tejada JL, Llera-Sastresa, E., \& Scarpellini, S. (2017). A multi-criteria sustainability assessment for biodiesel and liquefied natural gas as alternative fuels in transport systems. Journal of Natural Gas Science and Engineering, 42:169-186.

[20] Mihyeon Jeon C, \& Amekudzi, A. (2015). Addressing sustainability in transportation systems: Definitions, indicators, and metrics. Journal of Infrastructure Systems, 11(1):31-50.

[21] Shiftan Y, Kaplan, S., \& Hakkert, S. (2003). Scenario building as a tool for planning a sustainable transportation system. Transportation Research Part D: Transport and Environment, 8(5):323-342.

[22] Griškevičiūtè-Gečienè A, \& Griškevičienè, D. (2016). The Influence of Transport Infrastructure Development on Sustainable Living Environment in Lithuania. Procedia Engineering (134):215-223.

[23] Wang L. (2014). Framework for Evaluating Sustainability of Transport System in Megalopolis and its Application. IERI Procedia (9):110-116.

[24] Mahdinia I, Habibian, M., Hatamzadeh, Y., \& Gudmundsson, H. (2018). An indicator-based algorithm to measure transportation sustainability: A case study of 
the US states. Ecological Indicators (89):738-754.

[25] Awasthi A, \& Omrani, H. (2009) .A hybrid approach based on AHP and belief theory for evaluating sustainable transportation solutions. . HInternational Journal of Global Environmental Issues, 9(3):212-226.

[26] Byrne MR, \& Polonsky, M. J. (2001). Impediments to consumer adoption of sustainable transportation: Alternative fuel vehicles. . International Journal of Operations \& Production Management, 21(12):1521- 1538.

[27] Jeon CM, Amekudzi, A.A., Guensler, R.L. (2010). Evaluating plan alternatives for transportation system sustainability: atlanta metropolitan region. International Journal of Sustainable Transportation, 4(4):227-247.

[28] Litman T. (2005). Efficient vehicles versus efficient transportation. Comparing transportation energy conservation strategies. Transport Policy, 12(2):121-129.

[29] Deakin E. (2001). Sustainable Development and Sustainable Transportation: Strategies for Economic Prosperity, Environmental Quality, and Equity. Institute of Urban and Regional Development UC Berkeley.

[30] Litman T. (2007). Developing indicators for comprehensive and sustainable transport planning. Transportation Research Record: Journal of the Transportation Research Board:10-15.

[31] Haghshenas H, \& Vaziri, M. (2012). Urban sustainable transportation indicators for global comparison. . Urban sustainable transportation indicators for global comparison, 15(1):115-121.

[32] Salling KB, Pryn, M.R. (2015). Sustainable transport project evaluation and decision support: indicators and planning criteria for sustainable development. International Journal of Sustainable Development \& World Ecology, 22(4):346357.

[33] Litman T, \& Burwell, D. (2006). Issues in sustainable transportation. International Journal of Global Environmental Issues, 6(4):331-347.

[34] Zhao J, \& Melaina, M. W. (2006). Transition to hydrogen-based transportation in China: Lessons learned from alternative fuel vehicle programs in the United States and China. Energy Policy, 34(11):1299-1309.

[35] Garcia R, \& Freire, F. (2017). A review of fleet-based life-cycle approaches focusing on energy and environmental impacts of vehicles. Renewable and Sustainable Energy Reviews (79):935-945.

[36] Litman T. (2013). Transportation and public health. Annual Review of Public Health (34):217-233.

[37] Tzeng GH, Lin, C. W., \& Opricovic, S. (2005). Multi-criteria analysis of alternative-fuel buses for public transportation. Energy Policy, 33(11):1373-1383.

[38] Srisawat P, Kronprasert, N., \& Arunotayanun, K. (2017). Development of Decision Support System for Evaluating Spatial Efficiency of Regional Transport Logistics. . Transportation research procedia (25):4832-4851.

[39] Shiau TA, Huang, M. W., \& Lin, W. Y. (2015). Developing an indicator system for measuring Taiwan's transport sustainability. International Journal of Sustainable Transportation, 9(2):81-92.

[40] Djekic I, Smigic, N., Glavan, R., Miocinovic, J., \& Tomasevic, I. (2018). Transportation sustainability index in dairy industry-Fuzzy logic approach. . Journal of Cleaner Production (180):107-115. 
[41] Litman T. (2008). Valuing transit service quality improvements. Journal of Public transportation, 11(2):3.

[42] Russo F, \& Comi, A. (2011). A model system for the ex-ante assessment of city logistics measures. Research in transportation economics, 31(1):81-87.

[43] Zegras C. (2006). Sustainable transport indicators and assessment methodologies. In Biannual Conference and Exhibit of the Clean Air Initiative for Latin American Cities: 25-27.

[44] Ulengin F, Kabak, Ö., Önsel, Ş., Ülengin, B., \& Aktaş, E. (2010). A problemstructuring model for analyzing transportation-environment relationships. . European Journal of Operational Research, 200(3):844-859.

[45] Gudmundsson H. (2001). Indicators and performance measures for Transportation, Environment and Sustainability in North America. Ministry of Environment and Energy, National Environmental Research Institute.

[46] El-Diraby TE, Abdulhai, B., \& Pramod, K. C. (2005). The application of knowledge management to support the sustainable analysis of urban transportation infrastructure. Canadian Journal of Civil Engineering, 32(1):58-71.

[47] Gehin A, Zwolinski, P., \& Brissaud, D. (2008). A tool to implement sustainable end-of-life strategies in the product development phase. Journal of Cleaner Production, 16(5):566-576.

[48] Shiau TA, \& Liu, J. S. (2013). Developing an indicator system for local governments to evaluate transport sustainability strategies. Ecological Indicators (34):361-371.

[49] Shiau TA, \& Jhang, J. S. (2010). An integration model of DEA and RST for measuring transport sustainability. International Journal of Sustainable Development \& World Ecology, 17(1):76-83.

[50] Chang DY. (1996). Applications of the extent analysis method on fuzzy AHP. . European journal of operational research, 95(3):649-655.

[51] Ghadimi P, Azadnia, A. H., Yusof, N. M., \& Saman, M. Z. M. (2012). A weighted fuzzy approach for product sustainability assessment: a case study in automotive industry. Journal of Cleaner Production (33):10-21.

[52] Cornelissen AMG, van den Berg, J., Koops, W. J., Grossman, M., \& Udo, H. M. J. (2001). Assessment of the contribution of sustainability indicators to sustainable development: a novel approach using fuzzy set theory. . Agriculture, ecosystems \& environment, 86(2):173-185.

[53] Singh RN, \& Bailey, W. H. (1997). Fuzzy logic applications to multisensormultitarget correlation. IEEE Transactions on Aerospace and Electronic Systems, 33(3):752-769.

[54] Zadeh AE, \& Aredebilipour, M. (2008). Numerical methods for signal identification. Journal of Numerical Methods in Engineering, 5(2):34-42.

[55] Fathi A, \& Saen, R. F. (2018). A novel bidirectional network data envelopment analysis model for evaluating sustainability of distributive supply chains of transport companies. Journal of Cleaner Production (184):696-708.

[56] Ghadimi P, Dargi, A., \& Heavey, C. (2017). Sustainable supplier performance scoring using audition check-list based fuzzy inference system: A case application in automotive spare part industry. Computers \& Industrial Engineering, 105:12-27. 
[57] Ghadimi P, Toosi, F. G., \& Heavey, C. (2018). A multi-agent systems approach for sustainable supplier selection and order allocation in a partnership supply chain. . European Journal of Operational Research, 269(1):286-301.

[58] Ghadimi P, Azadnia, A. H., Heavey, C., Dolgui, A., \& Can, B. (2016). A review on the buyer-supplier dyad relationships in sustainable procurement context: past, present and future. International journal of production research, 54(5):1443-1462.

[59] Zimmer K, Fröhling, M., \& Schultmann, F. (2016). Sustainable supplier management-a review of models supporting sustainable supplier selection, monitoring and development. . International Journal of Production Research, 54(5):1412-1442.

[60] Fahimnia B, Bell, M. G., Hensher, D. A., \& Sarkis, J. (2015a). The Role of Green Logistics and Transportation in Sustainable Supply Chain. In Green Logistics and TransportationSpringer, Cham:1-12. 